\title{
Effect of different organic nutrient supplements on the total heterotrophic counts and diesel oil degradation in diesel polluted soil
}

\author{
C.O. AKUJOBI ${ }^{1 *}$, H.O. NJOKU ${ }^{2}$, N. ABANNO ${ }^{1}$, S.I. OKORONDU ${ }^{1}$ and \\ J.N. OGBULIE ${ }^{1}$ \\ ${ }^{1}$ Microbiology Department, Federal University of Technology, PM 1526, Owerri, Imo State, Nigeria. \\ ${ }^{2}$ Microbiology Department, University of Port Harcourt, Port Harcourt, Rivers State, Nigeria. \\ *Corresponding author, E-mail: campbell205@yahoo.com; Phone: +2348035426409.
}

\begin{abstract}
The effect of graded quantities of different organic nutrient supplements on the total heterotrophic counts and diesel oil degradation in diesel-polluted soil was studied. Soil samples were mixed with different volumes of diesel to obtain heavy and moderate pollution, which was subsequently amended with different quantities of organic nutrient supplements. Total heterotrophic counts were determined at two weeks intervals for 16 weeks and the oil and grease content were determined at the beginning and at the end of the study. The result showed a general increase in microbial count with increase in the quantities of supplement. Poultry waste-amended samples had the highest count in all the samples followed by pig waste and cow dung-amended samples. Diesel oil degradation followed the same order with the highest percentage oil degradation obtained in poultry waste-amended samples. It therefore, showed that poultry waste is the best organic waste to be applied in a biodegradation process.

(C) 2009 International Formulae Group. All rights reserved.
\end{abstract}

Keywords: Diesel oil, organic nutrients, biodegradation, heterotrophic microorganisms.

\section{INTRODUCTION}

Micro and macronutrients are required for the biodegradation of hydrocarbons. Macronutrients, especially nitrogen and phosphorus are the major limitations of biodegradation. Deficiencies in these nutrients affect the rate of biodegradation because they are needed for active metabolism, so the applications of these nutrients help to stimulate hydrocarbon degradation in the soil (Kovacheva et al., 2001). The adjustment of carbon, nitrogen and phosphorus ratio in an oil contaminated soil is highly beneficial to oil degradation (Benyahia et al., 2007). Addition of these nutrients can enhance biodegradation but excess of these nutrients in soil can repress metabolism. For example, high levels of nitrogen may inhibit microbial activities due to its toxic effect. (Kovacheva et al., 2001)

Transport of nutrients to the target zone may be difficult and will depend on soil physico-chemical properties. Soil generally contains sufficient nutrients to support the biodegradation of hydrocarbon in contaminated soil. The advantage of adding nutrients is to enhance the growth of organisms and to supply the limiting elements in the soil (Kovacheva et al., 2001). Margesin et al. (2006) reported that hydrocarbon biodegradation could be accelerated by sufficient nitrogen, phosphorus and other nutrients contained in fertilizer in aqueous environments and sediments. In addition to the biological properties of these fertilizers, some of them naturally act by chemically modifying the rheological properties of the oil 
being tested. Inorganic nutrients required for cell growth also include potassium, sulphur, magnesium, calcium, manganese, iron, zinc, copper and trace elements. If nutrients are not available in sufficient amount, microbial activity will become limited. Nitrogen and phosphorus are the nutrients most likely to be deficient in the contaminated environment. These are usually added to the bioremediation system in a usable form. In polluted site, there is low concentration of nitrogen and phosphorus. When there is oil pollution in such site, carbon concentration increases and the concentration of nitrogen and phosphorus becomes limited. In order to increase the rate of decomposition of hydrocarbon in such case, nitrogen will be added in the form of ammonia and phosphorus added in form of phosphates (Koshikawa et. al., 2001).

In general, microorganisms decompose organic substance to generate energy and nutrients for their growth. Thus, a usual consequence of biodegradation of a compound is increase in the number of microbes degrading that substance (Juhasz and Nadu, 2000). In a natural ecosystem, microbial species exist not in isolation but in the presence of a wide variety of other microbes. In some instances, transformation product generated by the reaction of one microbe may serve as a growth substrate for another. Alternatively, a chemical may completely be degraded by series of sequential co-metabolic attacks by microbial species. Thus cometabolism may be harmful in that the transformation can lead to the production of a compound with increased resistance to further degradation or may be of greater toxicity than the parent compound (Middleton et al., 2003). This work is undertaken to ascertain the best supplement for the bioremediation of diesel polluted soil and to determine the effect of increasing quantities of these supplement in enhancing the biodegradation of diesel polluted soil.

\section{MATERIALS AND METHODS}

The soil samples used for this study were collected from a site in the School of Agriculture and Agricultural Technology (SAAT), Federal University of Technology, Owerri (FUTO) Nigeria. The soil samples were collected from 5-10 cm of topsoil using a spade and transported to the preparation ground in clean plastic buckets. The diesel oil was obtained from Nigerian National Petroleum Corporation (NNPC) mega Station, Owerri, Nigeria. The cow dung was obtained from cattle ranch of the Department of Animal Production, FUTO, Nigeria. The pig and poultry waste were obtained from Songhai Redemption Farms, Nekede, Owerri, Nigeria, while the inorganic fertilizer (NPK 15:15:15) was obtained from ADC Farms, Nekede, Owerri, Nigeria.

Samples for heavy and moderate pollution were performed by mixing 20 litres and 10 litres of diesel respectively with $84 \mathrm{~kg}$ of soil and dispensed into perforated plastic buckets in $6 \mathrm{~kg}$ weights each. These were mixed with various quantities of organic and inorganic supplements (200-600 g). Samples were exposed to rain and sunlight throughout the period of study.

Soil samples were also obtained and dispensed in $6 \mathrm{~kg}$ weights in plastic buckets. The soil samples were mixed with diesel oil to achieve 2\%, 4\%, 6\%, $8 \%$ and $10 \%$ (w/v) pollution. Controls were set without diesel oil pollution.

Total heterotrophic bacterial and fungal populations in the soil were enumerated at two weeks interval till the $16^{\text {th }}$ week using the method of Nweke (2000). Mean of the duplicate colony counts was calculated and used to compute the number of heterotrophic microorganisms in the samples.

The oil and grease content of the polluted soil samples were determined at the beginning and the end of the study using the method of Edebiri (1987). Calculation of quantities of oil and grease in soil was done using the equation:

$\mathrm{Mg} / 100 \mathrm{~g}$ soil and grease $=\underline{(\mathrm{dE}-\mathrm{dB}) \times \text { vol.of solvent } \mathrm{X} 10^{5}}$ Wt of soil

Where $\mathrm{dE}=$ density of extract, $\mathrm{dB}=$ density of blank, vol of solvent $=$ volume of solvent for extraction.

This was used to calculate the quantity of oil degraded. The results were analysed statistically using analysis of variance (ANOVA) at $95 \%$ confidence interval.

\section{RESULTS}

The total heterotrophic bacterial counts in the heavily polluted soil sample are presented in Table 1. It was observed that there was increase in bacterial count from the 
$1^{\text {st }}$ week to the $8^{\text {th }}$ week and gradual decrease from the $10^{\text {th }}$ week till the end of the $16^{\text {th }}$ week in all the samples except in the control 1 (polluted soil without amendment) where the count increased from the $1^{\text {st }}$ week till the end of the $16^{\text {th }}$ week. In control 2 (unpolluted soil without amendment), the bacteria count varied per week but did not follow any particular sequence.

Among the supplemented samples, poultry waste $(600 \mathrm{~g})$ had the highest bacterial count in the $8^{\text {th }}$ week followed by the pig waste $(600 \mathrm{~g})$. The highest count was $8.21 \times 10^{7} \mathrm{cfu} / \mathrm{g}$ of soil while the lowest was $1.02 \times 10^{4} \mathrm{cfu} / \mathrm{g}$, which was obtained in the $1^{\text {st }}$ week in the soil sample amended with $200 \mathrm{~g}$ of inorganic fertilizer. Control 1 had counts ranging from $3.89 \times 10^{3} \mathrm{cfu} / \mathrm{g}$ to $4.89 \times 10^{6} \mathrm{cfu} / \mathrm{g}$ while control 2 had counts ranging from $2.80 \times 10^{10}$ to $4.89 \times 10^{11} \mathrm{cfu} / \mathrm{g}$.

There was no significant difference $(p<0.05)$ in the bacterial counts obtained per week but counts obtained in the unpolluted soil sample (control 2) were significantly higher $(\mathrm{p}<0.05)$ than those obtained in the polluted samples.

There was also an increase in bacterial count with an increase in supplement weight per week in the moderately polluted soil samples (Table 2). The bacterial counts increased from week 1 to week 10 in all the amended soil samples but decreased gradually from week 12 to week 16. Among the amended samples, $600 \mathrm{~g}$ poultry wastesupplemented samples had the highest counts in week $10\left(7.25 \times 10^{8} \mathrm{cfu} / \mathrm{g}\right)$, while the lowest count was obtained in the sample containing $200 \mathrm{~g}$ of inorganic fertilizer on the first week $\left(1.09 \times 10^{5} \mathrm{cfu} / \mathrm{g}\right)$. Control 1 had counts ranging from $2.05 \times 10^{5} \mathrm{cfu} / \mathrm{g}$ to $1.7 \times 10^{7} \mathrm{cfu} / \mathrm{g}$, which was obtained in the $1^{\text {st }}$ and $16^{\text {th }}$ weeks respectively. Bacterial counts from control 2 fluctuated within the sampling period. There were slight statistical differences in the bacterial count obtained in the various weeks at $\mathrm{p}<0.05$. The counts obtained in control 2 was significantly higher than those obtained in other treatments but no statistical difference among the supplemented weight $(\mathrm{p}<0.05)$.

Table 3 shows the total heterotrophic fungal counts in heavily polluted soil. The result showed that there was increase in the number of fungal counts from week 1 till week 16 in all the supplemented samples. The highest fungal count was obtained in the sample amended with $600 \mathrm{~g}$ of poultry waste obtained on the $16^{\text {th }}$ week $\left(1.78 \times 10^{6} \mathrm{cfu} / \mathrm{g}\right)$ while the lowest count was obtained in control 1 on the $1^{\text {st }}$ week $\left(1.20 \times 10^{6} \mathrm{cfu} / \mathrm{g}\right)$. Samples amended with poultry waste had the highest count per week among the amended samples followed by pig waste, cow dung and inorganic fertilizer. Counts obtained in the control 2 were significantly higher than those from the polluted samples but the counts fluctuated per week. The counts obtained in the $16^{\text {th }}$ week was significantly higher than those obtained in the other weeks $(\mathrm{p}<0.05)$.

The total heterotrophic fungal counts in moderately polluted soil samples are presented in Table 4. There was an increase in fungal count from the $1^{\text {st }}$ week till the $16^{\text {th }}$ week. In all the supplemented samples, the highest counts were obtained in the samples amended with the highest quantities of supplements while the lowest counts were obtained with the lowest quantities of supplements. Counts obtained in control 2 were significantly higher than those obtained in the other samples $(\mathrm{p}<0.05)$. Counts obtained in the $16^{\text {th }}$ week was significantly higher than those obtained in the other weeks at $\mathrm{p}<0.05$.

The result of the total heterotrophic bacterial and fungal counts of samples mixed with different percentage concentrations of diesel oil is presented in Table 5. The highest number of counts was obtained in the unpolluted soil samples $(0 \%$ diesel oil pollution) and the counts fluctuated per week. In the polluted samples, there were increase in the number of counts from the $1^{\text {st }}$ week to the $10^{\text {th }}$ week and a gradual decrease in microbial counts with percentage increase of diesel oil pollution. The bacterial counts were significantly higher than the fungal counts $(\mathrm{p}<0.05)$.

The percentage of diesel oil degraded in heavily and moderately polluted soil samples are presented in Table 6. It was observed that the higher the quantity of supplement, the higher the percentage of the diesel oil degraded in both heavily and moderately polluted samples. The highest percentage of diesel oil degraded was observed in $600 \mathrm{~g}$ poultry waste samples $(86.28 \%$ and $98.67 \%$ for heavily and moderately polluted soil samples respectively). These were followed by the 
C. O. AKUJOBI et al. / Int. J. Biol. Chem. Sci. 3(6): 1480-1490, 2009

Table 1: Effect of different soil supplements on total heterotrophic counts in heavily polluted soil.

\begin{tabular}{|c|c|c|c|c|c|c|c|c|c|c|}
\hline \multirow[t]{2}{*}{ Supplement } & \multirow{2}{*}{$\begin{array}{l}\text { Supplement } \\
\text { grades }(\mathrm{g})\end{array}$} & \multicolumn{3}{|l|}{ : } & \multicolumn{4}{|c|}{ Time (Weeks) and Fungal Counts (cfu/g) } & \multirow[b]{2}{*}{14} & \multirow[b]{2}{*}{16} \\
\hline & & g) & 2 & 4 & 6 & 8 & 10 & 12 & & \\
\hline \multirow{2}{*}{$\begin{array}{l}\text { Poultry } \\
\text { waste }\end{array}$} & 400 & $4.35 \times 10^{4}$ & $4.35 \times 10^{5}$ & $2.24 \times 10^{6}$ & $4.32 \times 10^{7}$ & $5.72 \times 10^{7}$ & $3.32 \times 10^{7}$ & $8.40 \times 10^{6}$ & $7.83 \times 10^{5}$ & $4.06 \times 10^{5}$ \\
\hline & 600 & $7.11 \times 10^{4}$ & $5.31 \times 10^{5}$ & $9.72 \times 10^{6}$ & $6.40 \times 10^{7}$ & $8.21 \times 10^{7}$ & $6.11 \times 10^{7}$ & $8.97 \times 10^{6}$ & $9.02 \times 10^{5}$ & $7.22 \times 10^{5}$ \\
\hline \multirow{3}{*}{$\begin{array}{c}\text { Pig } \\
\text { waste }\end{array}$} & 200 & $1.54 \times 10^{4}$ & $1.41 \times 10^{5}$ & $3.02 \times 10^{6}$ & $2.20 \times 10^{7}$ & $3.11 \times 10^{7}$ & $1.01 \times 10^{7}$ & $6.32 \times 10^{6}$ & $3.55 \times 10^{5}$ & $1.23 \times 10^{5}$ \\
\hline & 400 & $3.95 \times 10^{4}$ & $2.11 \times 10^{5}$ & $7.82 \times 10^{6}$ & $3.98 \times 10^{7}$ & $4.24 \times 10^{7}$ & $2.48 \times 10^{7}$ & $6.92 \times 10^{6}$ & $4.28 \times 10^{5}$ & $3.30 \times 10^{5}$ \\
\hline & 600 & $5.29 \times 10^{4}$ & $4.24 \times 10^{5}$ & $8.22 \times 10^{6}$ & $5.32 \times 10^{7}$ & $7.33 \times 10^{7}$ & $5.42 \times 10^{7}$ & $7.25 \times 10^{6}$ & $7.01 \times 10^{5}$ & $5.71 \times 10^{5}$ \\
\hline \multirow{3}{*}{$\begin{array}{l}\text { Cow } \\
\text { dung }\end{array}$} & 200 & $1.31 \times 10^{4}$ & $1.21 \times 10^{5}$ & $2.86 \times 10^{6}$ & $1.82 \times 10^{7}$ & $2.90 \times 10^{7}$ & $1.00 \times 10^{7}$ & $5.81 \times 10^{6}$ & $3.02 \times 10^{5}$ & $1.11 \times 10^{5}$ \\
\hline & 400 & $3.81 \times 10^{4}$ & $2.01 \times 10^{5}$ & $7.12 \times 10^{6}$ & $3.23 \times 10^{7}$ & $3.92 \times 10^{7}$ & $1.56 \times 10^{7}$ & $6.01 \times 10^{6}$ & $3.98 \times 10^{5}$ & $2.88 \times 10^{5}$ \\
\hline & 600 & $4.89 \times 10^{4}$ & $4.02 \times 10^{5}$ & $7.89 \times 10^{6}$ & $5.06 \times 10^{7}$ & $6.32 \times 10^{7}$ & $5.00 \times 10^{7}$ & $6.70 \times 10^{6}$ & $6.80 \times 10^{5}$ & $4.90 \times 10^{5}$ \\
\hline \multirow{2}{*}{$\begin{array}{l}\text { Inorganic } \\
\text { fertilizer }\end{array}$} & 200 & $1.02 \times 10^{4}$ & $9.89 \times 10^{4}$ & $2.21 \times 10^{6}$ & $1.06 \times 10^{7}$ & $2.14 \times 10^{7}$ & $9.84 \times 10^{6}$ & $4.90 \times 10^{6}$ & $2.74 \times 10^{5}$ & $1.00 \times 10^{5}$ \\
\hline & 600 & $4.02 \times 10^{4}$ & $3.54 \times 10^{5}$ & $7.10 \times 10^{6}$ & $4.03 \times 10^{7}$ & $5.82 \times 10^{7}$ & $4.82 \times 10^{7}$ & $4.28 \times 10^{6}$ & $5.81 \times 10^{5}$ & $4.01 \times 10^{5}$ \\
\hline \multirow{2}{*}{\multicolumn{2}{|c|}{$\begin{array}{l}\text { Control } 1 \\
\text { Control } 2\end{array}$}} & $3.89 \times 10^{3}$ & $4.89 \times 10^{3}$ & $9.78 \times 10^{3}$ & $1.06 \times 10^{4}$ & $5.60 \times 10^{4}$ & $6.88 \times 10^{5}$ & $7.02 \times 10^{5}$ & $3.02 \times 10^{6}$ & $4.89 \times 10^{6}$ \\
\hline & & $3.20 \times 10^{10}$ & $4.30 \times 10^{10}$ & $2.80 \times 10^{10}$ & $2.70 \times 10^{11}$ & $3.22 \times 10^{11}$ & $4.89 \times 10^{10}$ & $6.86 \times 10^{10}$ & $3.24 \times 10^{11}$ & $4.89 \times 10^{11}$ \\
\hline
\end{tabular}


C. O. AKUJOBI et al. /Int. J. Biol. Chem. Sci. 3(6): 1480-1490, 2009

Table 2: Effect of different soil supplements on total heterotrophic bacterial counts in moderately polluted soil.

\begin{tabular}{|c|c|c|c|c|c|c|c|c|c|c|}
\hline \multirow[t]{2}{*}{ Supplement } & \multirow{2}{*}{$\begin{array}{l}\text { Supplement } \\
\text { grades (g) }\end{array}$} & \multicolumn{9}{|c|}{ Time (Weeks) and Fungal Counts (cfu/g) } \\
\hline & & ) & 2 & 4 & 6 & 8 & 10 & 12 & 14 & 16 \\
\hline Poultry & 200 & $2.81 \times 10^{5}$ & $1.32 \times 10^{6}$ & $3.11 \times 10^{7}$ & $2.10 \times 10^{8}$ & $4.31 \times 10^{8}$ & $3.24 \times 10^{8}$ & $9.01 \times 10^{7}$ & $5.02 \times 10^{6}$ & $3.20 \times 10^{6}$ \\
\hline Waste & $\begin{array}{l}400 \\
600\end{array}$ & $\begin{array}{l}3.01 \times 10^{5} \\
5.11 \times 10^{5}\end{array}$ & $\begin{array}{l}2.21 \times 10^{6} \\
3.84 \times 10^{6}\end{array}$ & $\begin{array}{l}3.89 \times 10^{7} \\
4.01 \times 10^{7}\end{array}$ & $\begin{array}{l}4.36 \times 10^{8} \\
4.98 \times 10^{8}\end{array}$ & $\begin{array}{l}4.89 \times 10^{8} \\
5.01 \times 10^{8}\end{array}$ & $\begin{array}{l}6.64 \times 10^{8} \\
7.25 \times 10^{8}\end{array}$ & $\begin{array}{l}1.03 \times 10^{8} \\
2.03 \times 10^{8}\end{array}$ & $\begin{array}{l}7.34 \times 10^{6} \\
9.58 \times 10^{6}\end{array}$ & $\begin{array}{l}5.84 \times 10^{6} \\
7.36 \times 10^{6}\end{array}$ \\
\hline Pig & 200 & $2.03 \times 10^{5}$ & $9.86 \times 10^{5}$ & $2.63 \times 10^{7}$ & $1.97 \times 10^{8}$ & $2.84 \times 10^{8}$ & $1.20 \times 10^{8}$ & $7.93 \times 10^{7}$ & $4.76 \times 10^{6}$ & $1.28 \times 10^{6}$ \\
\hline Waste & $\begin{array}{l}400 \\
600\end{array}$ & $\begin{array}{l}2.70 \times 10^{5} \\
4.04 \times 10^{5}\end{array}$ & $\begin{array}{l}1.17 \times 10^{6} \\
2.96 \times 10^{6}\end{array}$ & $\begin{array}{l}2.95 \times 10^{7} \\
3.88 \times 10^{7}\end{array}$ & $\begin{array}{l}3.01 \times 10^{8} \\
4.06 \times 10^{8}\end{array}$ & $\begin{array}{l}3.94 \times 10^{8} \\
4.21 \times 10^{8}\end{array}$ & $\begin{array}{l}5.23 \times 10^{8} \\
6.21 \times 10^{8}\end{array}$ & $\begin{array}{l}9.76 \times 10^{7} \\
1.11 \times 10^{8}\end{array}$ & $\begin{array}{l}6.44 \times 10^{6} \\
7.01 \times 10^{6}\end{array}$ & $\begin{array}{l}3.29 \times 10^{6} \\
5.88 \times 10^{6}\end{array}$ \\
\hline Cow & 200 & $1.64 \times 10^{5}$ & $7.84 \times 10^{5}$ & $1.88 \times 10^{7}$ & $1.06 \times 10^{8}$ & $1.96 \times 10^{8}$ & $9.87 \times 10^{7}$ & $6.54 \times 10^{7}$ & $3.98 \times 10^{6}$ & $1.12 \times 10^{6}$ \\
\hline dung & $\begin{array}{l}400 \\
600\end{array}$ & $\begin{array}{l}2.46 \times 10^{5} \\
3.66 \times 10^{5}\end{array}$ & $\begin{array}{l}9.78 \times 10^{5} \\
2.03 \times 10^{6}\end{array}$ & $\begin{array}{l}2.01 \times 10^{7} \\
2.21 \times 10^{7}\end{array}$ & $\begin{array}{l}2.94 \times 10^{8} \\
3.65 \times 10^{8}\end{array}$ & $\begin{array}{l}3.02 \times 10^{8} \\
3.96 \times 10^{8}\end{array}$ & $\begin{array}{l}4.86 \times 10^{8} \\
5.63 \times 10^{8}\end{array}$ & $\begin{array}{l}7.25 \times 10^{7} \\
9.87 \times 10^{7}\end{array}$ & $\begin{array}{l}5.70 \times 10^{6} \\
6.84 \times 10^{6}\end{array}$ & $\begin{array}{l}2.60 \times 10^{6} \\
4.01 \times 10^{6}\end{array}$ \\
\hline Inorganic & 200 & $1.09 \times 10^{5}$ & $6.77 \times 10^{5}$ & $1.21 \times 10^{7}$ & $9.87 \times 10^{7}$ & $1.13 \times 10^{8}$ & $9.06 \times 10^{7}$ & $6.03 \times 10^{7}$ & $3.11 \times 10^{6}$ & $9.84 \times 10^{5}$ \\
\hline fertilizer & $\begin{array}{l}400 \\
600\end{array}$ & $\begin{array}{l}1.95 \times 10^{5} \\
3.11 \times 10^{5}\end{array}$ & $\begin{array}{l}9.03 \times 10^{5} \\
1.83 \times 10^{6}\end{array}$ & $\begin{array}{l}1.66 \times 10^{7} \\
1.98 \times 10^{7}\end{array}$ & $\begin{array}{l}2.01 \times 10^{8} \\
2.87 \times 10^{8}\end{array}$ & $\begin{array}{l}2.96 \times 10^{8} \\
3.03 \times 10^{8}\end{array}$ & $\begin{array}{l}4.01 \times 10^{8} \\
4.91 \times 10^{8}\end{array}$ & $\begin{array}{l}6.88 \times 10^{7} \\
8.01 \times 10^{7}\end{array}$ & $\begin{array}{l}5.11 \times 10^{6} \\
6.04 \times 10^{6}\end{array}$ & $\begin{array}{l}1.94 \times 10^{6} \\
3.93 \times 10^{6}\end{array}$ \\
\hline Control & 1 & $2.03 \times 10^{5}$ & $2.89 \times 10^{5}$ & $4.64 \times 10^{5}$ & $5.32 \times 10^{6}$ & $9.87 \times 10^{6}$ & $1.21 \times 10^{7}$ & $3.42 \times 10^{7}$ & $2.20 \times 10^{7}$ & $1.76 \times 10^{7}$ \\
\hline Control & 2 & $3.20 \times 10^{10}$ & $4.30 \times 10^{10}$ & $2.80 \times 10^{10}$ & $2.70 \times 10^{11}$ & $3.22 \times 10^{11}$ & $4.89 \times 10^{10}$ & $6.86 \times 10^{10}$ & $3.24 \times 10^{11}$ & $4.89 \times 10^{11}$ \\
\hline
\end{tabular}


C. O. AKUJOBI et al. /Int. J. Biol. Chem. Sci. 3(6): 1480-1490, 2009

Table 3: Effect of different soil supplements on total heterotrophic fungal counts in heavily polluted soil.

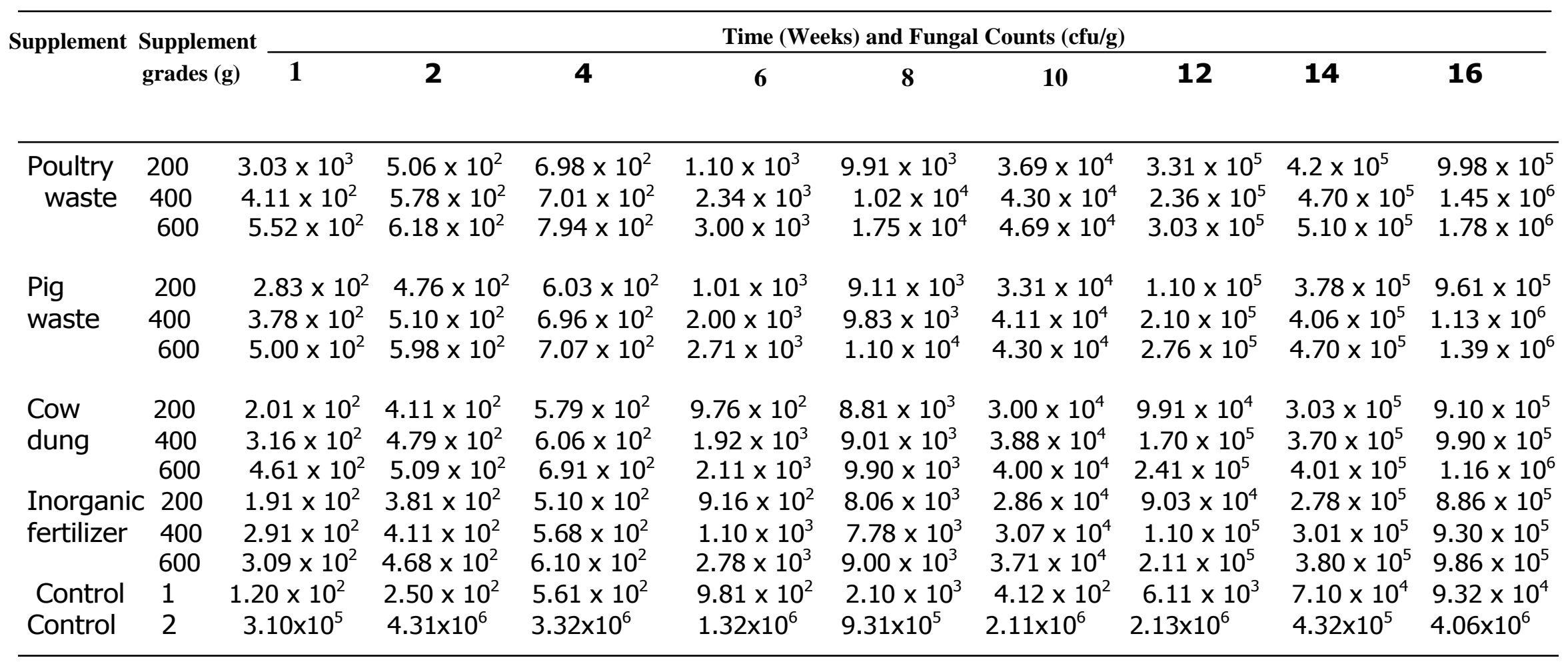


C. O. AKUJOBI et al. / Int. J. Biol. Chem. Sci. 3(6): 1480-1490, 2009

Table 4: Effect of different soil supplements on total heterotrophic fungal counts in moderately polluted soil.

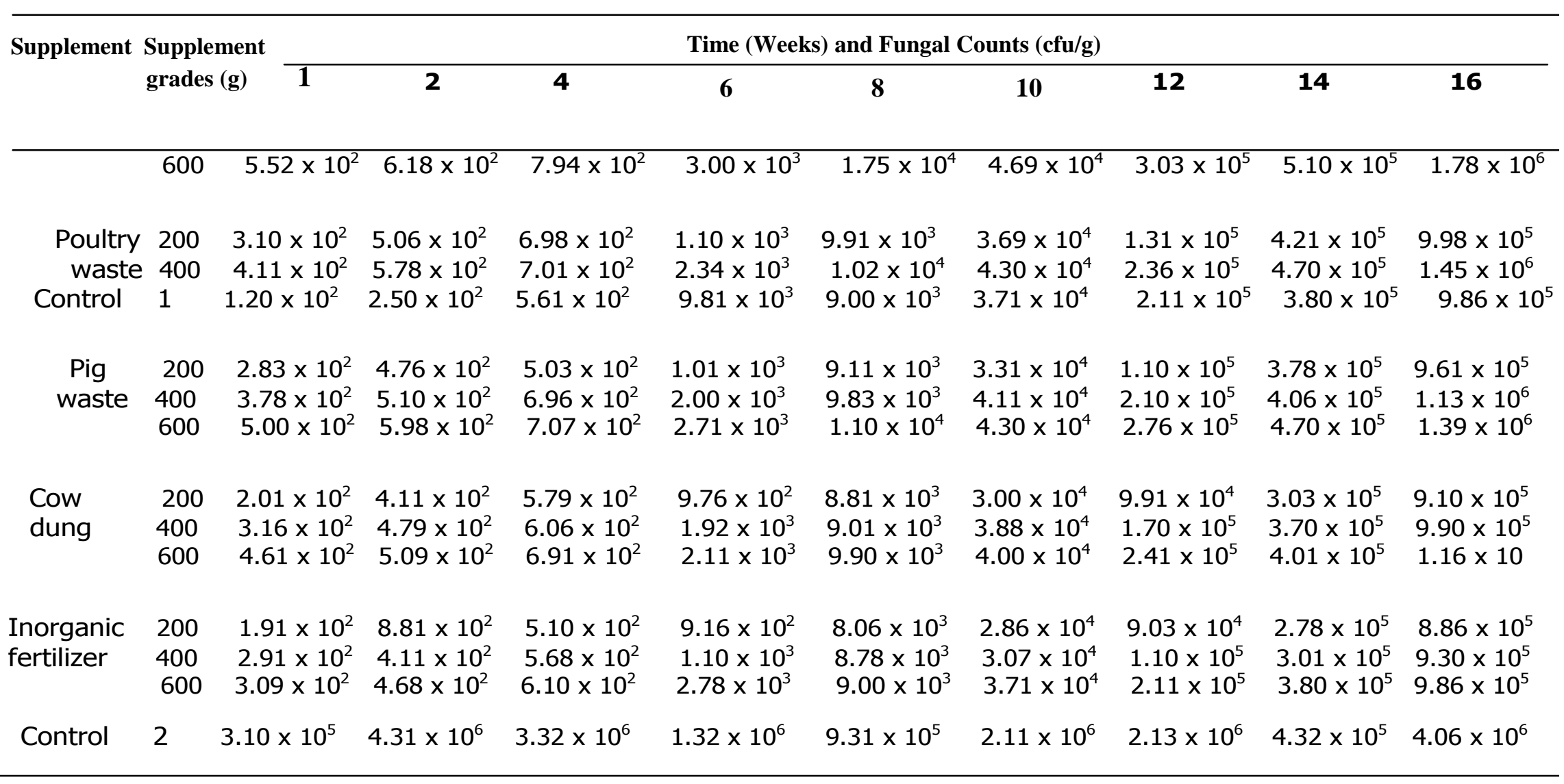


Table 5: Effect of different concentrations of diesel oil on total heterotrophic bacterial and fungal.

\begin{tabular}{|c|c|c|c|c|c|c|c|c|c|c|}
\hline \multirow{2}{*}{ Organisms } & \multirow{2}{*}{$\begin{array}{l}\text { Graded } \\
\text { samples (\%) }\end{array}$} & \multicolumn{9}{|c|}{ Time (weeks) } \\
\hline & & 1 & 2 & 4 & 6 & 8 & 10 & 12 & 14 & 16 \\
\hline \multirow{6}{*}{$\begin{array}{l}\text { Fungal } \\
\text { Counts } \\
\text { (cfu/g) }\end{array}$} & 0 & $3.10 \times 10^{5}$ & $4.31 \times 10^{6}$ & $3.32 \times 10^{6}$ & $1.32 \times 10^{6}$ & $9.31 \times 10^{5}$ & $2.11 \times 10^{6}$ & $2.13 \times 10^{5}$ & $4.32 \times 10^{5}$ & $4.06 \times 10^{6}$ \\
\hline & 2 & $2.36 \times 10^{4}$ & $9.09 \times 10^{4}$ & $1.38 \times 10^{5}$ & $8.89 \times 10^{5}$ & $1.32 \times 10^{6}$ & $3.01 \times 10^{6}$ & $1.79 \times 10^{6}$ & $4.01 \times 10^{5}$ & $2.16 \times 10^{5}$ \\
\hline & 4 & $2.01 \times 10^{4}$ & $7.24 \times 10^{4}$ & $9.10 \times 10^{4}$ & $5.08 \times 10^{5}$ & $8.90 \times 10^{5}$ & $2.13 \times 10^{6}$ & $9.30 \times 10^{5}$ & $3.14 \times 10^{5}$ & $1.20 \times 105^{5}$ \\
\hline & 6 & $1.03 \times 10^{4}$ & $3.30 \times 10^{4}$ & $5.26 \times 10^{5}$ & $2.98 \times 10^{5}$ & $5.10 \times 10^{5}$ & $1.11 \times 10^{6}$ & $7.70 \times 10^{5}$ & $2.16 \times 10^{5}$ & $8.26 \times 10^{4}$ \\
\hline & 8 & $7.80 \times 10^{3}$ & $1.26 \times 10^{4}$ & $3.17 \times 10^{4}$ & $1.01 \times 10^{5}$ & $3.20 \times 10^{5}$ & $8.10 \times 10^{5}$ & $9.30 \times 10^{5}$ & $7.42 \times 10^{5}$ & $6.24 \times 10^{5}$ \\
\hline & 10 & $5.10 \times 10^{3}$ & $8.36 \times 10^{3}$ & $1.12 \times 10^{4}$ & $3.36 \times 10^{4}$ & $9.01 \times 10^{4}$ & $1.20 \times 10^{4}$ & $3.26 \times 10^{5}$ & $5.11 \times 10^{5}$ & $6.10 \times 10^{5}$ \\
\hline \multirow{6}{*}{$\begin{array}{l}\text { Bacterial } \\
\text { Counts } \\
\text { (cfu/g) }\end{array}$} & 0 & $3.20 \times 10^{10}$ & $4.30 \times 10^{3}$ & $2.80 \times 10^{10}$ & $2.70 \times 10^{11}$ & $3.22 \times 10^{11}$ & $4.89 \times 10^{10}$ & $6.86 \times 10^{10}$ & $3.24 \times 10^{11}$ & $4.89 \times 10^{11}$ \\
\hline & 12 & $4.01 \times 10^{6}$ & $6.20 \times 10^{6}$ & $8.11 \times 10^{6}$ & $1.32 \times 10^{7}$ & $3.32 \times 10^{7}$ & $5.02 \times 10^{7}$ & $2.11 \times 10^{7}$ & $1.01 \times 10^{7}$ & $8.10 \times 10^{6}$ \\
\hline & 4 & $2.10 \times 10^{6}$ & $4.11 \times 10^{6}$ & $5.24 \times 10^{6}$ & $8.01 \times 10^{6}$ & $1.31 \times 10^{7}$ & $2.10 \times 10^{7}$ & $1.98 \times 10^{7}$ & $8.86 \times 10^{6}$ & $5.16 \times 10^{6}$ \\
\hline & 6 & $1.16 \times 10^{5}$ & $2.08 \times 10^{6}$ & $3.75 \times 10^{6}$ & $5.91 \times 10^{6}$ & $9.32 \times 10^{6}$ & $1.21 \times 10^{7}$ & $9.56 \times 10^{6}$ & $6.11 \times 10^{6}$ & $3.24 \times 10^{6}$ \\
\hline & 8 & $3.35 \times 10^{5}$ & $3.89 \times 10^{5}$ & $6.26 \times 10^{5}$ & $8.91 \times 10^{5}$ & $1.01 \times 10^{6}$ & $1.98 \times 10^{6}$ & $2.01 \times 10^{6}$ & $3.26 \times 10^{6}$ & $5.33 \times 10^{6}$ \\
\hline & 10 & $3.01 \times 10^{5}$ & $3.11 \times 10^{5}$ & $5.25 \times 10^{5}$ & $8.03 \times 10^{5}$ & $9.88 \times 10^{5}$ & $1.00 \times 10^{6}$ & $1.92 \times 10^{6}$ & $3.11 \times 10^{6}$ & $3.10 \times 10^{6}$ \\
\hline
\end{tabular}


Table 6: Quantity and percentage of oil degraded in heavily and moderately polluted soil samples.

\begin{tabular}{cccccc}
\hline Supplements & $\begin{array}{c}\text { Supplements } \\
\text { grades (g) }\end{array}$ & \multicolumn{2}{c}{$\begin{array}{c}\text { Quantity of oil degraded } \\
(\mathbf{m g} / \mathbf{1 0 0 g} \text { of soil) }\end{array}$} & \multicolumn{2}{c}{$\begin{array}{c}\text { \% quantity of oil } \\
\text { degraded }\end{array}$} \\
\cline { 3 - 6 } & & heavy & moderate & heavy & moderate \\
& & pollution & pollution & pollution & pollution \\
\hline Poultry & 200 & 3211.30 & 1987.30 & 76.20 & 94.31 \\
waste & 400 & 3385.77 & 2037.87 & 80.34 & 96.71 \\
& 600 & 3636.10 & 2079.17 & 86.28 & 98.67 \\
& 200 & 3106.36 & 1953.59 & 73.71 & 92.71 \\
Pig & 400 & 3249.23 & 1959.91 & 77.10 & 93.01 \\
waste & 600 & 3439.29 & 2018.70 & 81.61 & 95.80 \\
& 200 & 2907.02 & 1803.76 & 68.98 & 85.60 \\
Cow & 400 & 3083.18 & 1915.23 & 73.16 & 90.89 \\
dung & 600 & 3207.50 & 1965.17 & 76.11 & 93.26 \\
& 200 & 2709.79 & 1845.91 & 64.30 & 87.60 \\
Inorganic & 400 & 2870.36 & 1880.89 & 68.11 & 89.26 \\
fertilizer & 600 & 3087.40 & 1934.83 & 73.26 & 91.82 \\
Control & & 1820.58 & 1097.01 & 43.20 & 52.06 \\
\hline
\end{tabular}

$600 \mathrm{~g}$ pig waste samples $(81.61 \%$ and $95.80 \%$ for heavily and moderately polluted soil samples respectively), while the least were obtained in the polluted control samples $(43.20 \%$ and $52.06 \%$ for heavily and moderately polluted soil samples, respectively). Generally, diesel oil degradation achieved in the different samples was in the following order: poultry waste > pig waste > cow dung > inorganic fertilizer > control. The quantities of diesel oil degraded in the heavily polluted soil samples were significantly higher than those of the moderately polluted soil samples $(\mathrm{p}<0.05)$.

\section{DISCUSSION}

The response of the soil microbial community to the diesel oil showed that the pollutants stimulated the growth of heterotrophic microorganisms. The growth of the bacteria species increased progressively till the $10^{\text {th }}$ week in both heavily and moderately polluted soil samples. Generally, there were more counts in the poultry wasteamended samples, followed by the pig waste, cow dung and inorganic fertilizer amended samples in all the treatments. Considering the fact that both cow and pig have urinary systems which help in the excretion of nitrogenous substances, which are vital for the growth of microorganisms and for the fact that poultry do not have urinary systems, it could be reasoned that the nitrogenous substances in the poultry waste could be higher than in the waste from pig and cow. This could lead to the higher counts observed in the samples amended with poultry waste. The difference in the feed components of pig and cow, which may translate to difference in the components of their faecal matter, could be the reason for the difference in counts obtained in the pig waste and cow dung-amended samples.

The fungal counts in both heavily and moderately polluted samples amended with supplements increased gradually from the $1^{\text {st }}$ week till the $16^{\text {th }}$ week. From the results, it appears that the fungal species are secondary degraders of the diesel oil and will not grow significantly until the bacterial species, which seem to be the primary degraders, must have degraded some components of the diesel oil. The fungal species are, therefore, dependent on diesel intermediates produced by the bacterial species. However, in all the samples, highest counts were obtained in poultry wasteamended samples and the greater the quantity of supplements, the greater the counts. This shows that the organic supplements have direct effect on the growth of the microorganisms and hence in the utilization of 
diesel oil by bacteria species. This is in accordance with the works of Gentry et al. (2002) who proved that the addition of nutrients in the form of nitrogen and phosphorus would allow the soil microbial population to proliferate and metabolize the pollutant in question.

The microbial counts in samples mixed with different percentage concentrations of the diesel oil showed that there were decreases in microbial counts with percentage increase of diesel oil pollution. When diesel oil is present in the soil, it limits soil aeration and alters the general biogeochemical cycle of the soil in which it is present and creates an unconducive environment for some microorganisms (Zhou et al., 2000; Seklemora et al., 2001). This could be part of the reason why the number of counts decreased with an increase in the percentage concentration of diesel oil observed in this study. Boyd and Ganey (2005) and Fraser et al. (2006) also stated that xenobiotics may affect the physiological processes, genetic machinery and population of microorganisms and this could have direct bearing on the result of the present study.

The percentage quantity of oil degraded in both heavily and moderately polluted samples show that more percentage of diesel oil was degraded in moderately polluted than the heavily polluted soil in all the samples. This may be attributed to the deleterious effect of diesel oil, which may have had more effect on the proliferation of the microorganisms that resulted in their low metabolic rate in the heavily polluted soil. This is in consonance with the work of Admon et al. (2001) which stated that petroleum hydrocarbon impedes on the activity of microorganisms, thus limiting the biodegradation potential. Moreover, the diesel oil may have blocked the air spaces in the soil. Maila and Cloete (2004) stated that efficient oxygen supply to contaminated site is critical for biodegradation because dissolved oxygen depletion is the primary factor limiting aerobic degradation and this may have accounted for the lower percentage degradation of the diesel oil observed in the heavily polluted soil. Generally, more percentage of diesel oil was degraded in poultry and pig waste amended samples showing that poultry and pig waste may have more nutrients for the proliferation of the microorganisms, which resulted in higher degradation of the diesel oil. The quantities of oil degraded in the organic nutrientssupplemented samples were higher than those in the inorganic fertilizer-supplemented samples. It could be recalled that inorganic fertilizer (NPK) contains nitrogen, phosphorus and potassium including some heavy metals (Dinev and Koutev, 2003), so there may have been other nutrients apart from those mentioned above (being a mixture of substances) that helped in the degradation of diesel oil. Moreover, these metals contained in the inorganic fertilizer may exert some inhibitory effects on the microbial community. Knezevich et al. (2006) proved that both micro and macronutrients are required for the biodegradation of hydrocarbons and deficiency in any of these nutrients affects the rate of biodegradation. This could be the reason for the higher degradation observed in the organic wastesupplemented samples coupled with the inhibitory effect of the heavy metals which may have retarded the growth of the organisms in the inorganic fertilizer-amended samples. The result of this study showed that diesel oil is degradable by a wide range of microorganisms. In the soil, the rate of biodegradation of diesel oil can be increased by addition of organic wastes. The higher the quantity of organic waste added, the higher the rate of biodegradation and the shorter the time to remove the diesel pollutant from the soil. Poultry waste proved the best organic waste to be applied in biodegradation process followed by pig waste.

\section{REFERENCES}

Admon S, Green M, Avimelech L. 2001. Biodegradation kinetics of hydrocarbon in soil during land treatment of oil sludge. Biorem. Journ., 5(3): 193-209.

Benyahia F, Abdulkarim M, Mohamed AO. 2007. Bioaugmentation and biostimulation studies in the bioremediation of crude oil contaminated UAE soils. $J$. UAE Coll. Eng., 3: 214-219.

Boyd SA, Ganey PE. 2005. An approach to evaluation of the effect of biodegradation on biological activity of environmental contaminants: Dechlorination of polychlorinated biphenyls. Environ. Health Persp., 113(2): 180-185. 
Dinev N, Koutev V. 2003. Management of the bioavailability of heavy metals by organic and mineral amelioration of polluted soils. Bulg. J. Ecol. Sci., 2(3/4): 135-137.

Edebiri RAO. 1987. Partition-differential density method for the quantitative determination of oil and grease in water. In Proceedings of 1987 International Seminar on Petroleum Industry and Nigerian Environment. NNPC: Lagos; 157-159.

Fraser RL, Beyret E, Milligan SR, AgeoyaOsiguwa M. 2006. Effects of estrogenic xenobiotics on human and mouse spermatozoa. Hum. Reprod., 21(5): 11841193.

Gentry TJ, Josephson KL, Newby DT, Pepper IL, Roane TM. 2002. The role of cell bioaugmentation and gene bioaugmentation in the remediation of cocontaminated soils. Environ. Health Persp., 110(6): 287-299.

Juhasz SL, Naidu R. 2000. Enrichment and isolation of non-specific aromatic degraders from unique uncontaminated soils. J. Appl. Microbiol., 89(4): 642-650.

Knezevich V, Koren O, Ron EZ, Rosenberg E. 2006. Petroleum bioremediation in sea water using Guano as the fertilizer. $J$. Bioremed., 10(3): 83-91.

Koshikawa H, Nakahara T, Ogino A, Uchiyama H. 2001. Succession of microbial communities during a biostimulation process as evaluated by DGGE and clone library analysis. J. Appl. Microbiol., 91: 625-635.
Kovacheva K, Pavlova A, Seklomova E. 2001. Biostimulation-based bioremediation of diesel fuel: Field demonstration. Biodegrad., 12(5): 311316.

Maila MP, Cloete TE. 2004. Bioremediation of petroleum hydrocarbons through landfarming: are simplicity and cost effectiveness the only advantages. Rev. Environ. Sci. Biotechnol., 3(4): 349-360.

Margesin R, Cinadom J, Schinner F. 2006. Biological activity during composting of sewage sludge at low temperature. Int. Biotech. Biodegrad., 57: 88-92.

Middleton SS, Latmani RB, Mackey T, Elliman MH, Tebo BM, Criddle CS. 2003. Co-metabolism of $\mathrm{Cr}(\mathrm{VI})$ by Shewanella oneiderisis MR-1 produces cell- associated reduced chromium and inhibits growth. Biotechnol. Bioeng., 83(6): 627-637.

Nweke CE. 2000. Bioremediation of soil contaminated with a drilling fluid. MSc thesis. University of Port Harcourt, 37.

Seklemora E, Pavlora A, Koracheva K. 2001. Biostimulation-based bioremediation of diesel fuel field demonstration. Biodegrad., 12: 311- 316.

Zhou BX, Treves DS, Wu LY, Marsh TC, O'Neil RV, Pollumbo AV, Tiedje JM. 2002. Spatial and resource factors influencing high microbial diversity in soil. Appl. Environ. Microbiol., 68: 326334. 